\title{
NUP214/ABL1 Fusion Gene Variant 2
}

National Cancer Institute

\section{Source}

National Cancer Institute. NUP214/ABL1 Fusion Gene Variant 2. NCI Thesaurus. Code C99192.

A fusion gene that results from a chromosomal rearrang ement of $9 q 34$ which fuses the 5 ' half of the NUP214 gene with intron 1 of the ABL1 gene. This fusion is associated with T-cell acute lymphoblastic leukemia. 